\title{
BUILDING A GLOBAL FUTURE THROUGH RESEARCH AND INNOVATIVE PRACTICES IN OPEN AND DISTANCE LEARNING
}

\author{
Lecturer, Sheikh Tariq MAHMOOD \\ Lecturer, Dr. Azhar MAHMOOD \\ International Islamic University Islamabad, PAKISTAN
}

\begin{abstract}
The current study aims to investigate awareness of research students about the concept of plagiarism and to suggest possible ways to avoid it; a descriptive survey study was conducted. The objectives of the study were to examine the researcher's knowledge about concept of plagiarism, knowledge about specific terminologies, types of plagiarism, and consequences of plagiarism and to suggest possible ways to avoid it. Study was delimited to the research students of Faculty of Education at PhD, M.Phil. and MA level in Allma Iqbal Open University. A sample of hundred students was selected through snowball sampling technique, five point Likert scale questionnaire was used to collect the data. Data were analyzed through descriptive statistics. Major finding were that most of the students had misconception of plagiarism, most of them were unaware about the specific terminologies and types of plagiarism. Majority of the students were unaware about the consequences of plagiarism. On the basis of findings it was concluded that they were not properly taught about the concept of plagiarism during their course work in research and it had implications on the quality of research. The major recommendations were to add sufficient material about plagiarism in research courses and students may be informed about the HEC polices about plagiarism.
\end{abstract}

Keywords: Plagiarism, potluck paper, poor disguise, self stealer, misinformer

\section{INTRODUCTION}

In the era of globalization the DE is a growing source of education to masses. While focusing on quantity sometime quality suffers. University like Allama Iqbal Open University in Pakistan is playing an important role in promoting higher education. The higher level degrees needs research work and this research work is the source through which internal and global changes are possible. Research is the application of scientific method to solve a problem. Research is not a common way of acquiring knowledge it is a systematic way of acquiring and reporting. Research is scholarly writing. Research work may be within acceptable academic standards (De Lambert, 2006). 
The basis of such practice is sound referencing and a reflection on the ethics of research. One of the major flip-sides to proper academic standards is plagiarism. This has taken on a new importance in an era of widespread internet accessibility. Internet provided new opportunities to researcher globally, not only for conducting research and gathering knowledge, but also for cheating. Increasingly we need to be aware of the importance of ethics of research. Ethics in research is not a watertight science; however there are acceptable and unacceptable codes of conducts. (Grix, 2004)

Researchers acquire the knowledge from different sources of knowledge and provide empirical justifications about his/her claims. To improve the quality practice universities are doing different efforts. To control and maintain the standards of research within the universities Quality Enhancement Cell (QEC) are working and these are overall guided by the Higher Education Commission in Pakistan. In the preamble of HEC Plagiarism policy it is clearly describe that "A Plagiarism Policy has therefore become necessary to create awareness, define various forms in which Plagiarism exhibits itself, present a methodology of investigation, cater for punitive action proportional to the extent of the offence and even address the issue of false or spurious complaints".

The policy is applicable to students, teachers, researchers and staff of all institutions and organizations in Pakistan who are involved in writing or publishing their work. (HEC, 2006).This is one side of the coin that institutions have policies to tackle the problem of plagiarism, but the other side of the coin is, either the researchers have the concept clarity or awareness about the plagiarism. According to research by Ghulam (2013) "An extensive lack was found in the understanding of students towards plagiarism across all the universities". Majority of students in research are always ready to adopt inappropriate way and so they are at risk of punishment in the form of plagiarism penalty. In case of plagiarism detection there was an unreasonable perception of the students about the consequences and consider as taken granted. They are of the view that plagiarism is not that much bad and it must not end with penalties (Ghulam, 2013). Academic delinquency appears to be prevalent in each and every discipline with little variations due to the differences in influencing factors such as unawareness. The disciplinary areas in which there is presence of carelessness in academic behavior, the reason is found to be lack of awareness. There are also other reasons such as work-load which cause academic dishonest (Aggarwal, 2006; Marsden, 2005 \& Hardigan, 2004). The intent of the present study was to find out the awareness of research students in Distance Education about the concept of plagiarism and to suggest possible ways to avoid it; a descriptive survey study was conducted.

\section{OBJECTIVE OF THE STUDY}

The objectives of the study were to examine the researcher's knowledge about concept of plagiarism, knowledge about specific terminologies, types of plagiarism, and consequences of plagiarism. 


\section{REVIEW OF LITERATURE}

The Formal system of education alone cannot cater the needs of growing population. The main objective of DE has been the development of the individual as a whole.

It focuses on the learners' cultural, behavioral, mental capacity, understanding capability, and rational attitude. Seeing through globalized telescope, it is viewed that in the present borderless information society, education needs to respond to the additional demands by raising awareness of environment, research, cultural and social diversity. Education trains the individual to connect and live in harmony with the environment around him or her. Everything is in a state of constant flux. In this flow, educational system has changed its size, nature and its corpus. In this regard, the challenge for ODL system is to bring reforms, create and develop the systems that trained the individual to work in a borderless economy and live in a global society, by doing all this quality in the main component which has to be address (Sataya, 2008).

Globalization creates new ideas, values, identities, practices, and movements. In the globalization era, the world is becoming a more open and independent place in which people have a better chance of discovering their common humanity and sharing. Hence, it is viewed that globalization is a progressive transformation of knowledge and learning experience (Sataya,2008). A lot had been written about "distance learning" and "distance education" but not "distance teaching". However, all definitions have some elements in common. According to Keegan's equation: "distance teaching" + "distance learning" = "distance education". The term "distance education" is more comprehensive and precise despite the every-day usage of the term "distance learning". puts it in the right context: 'Distance education means creating educational communities which teachers, students and others are linked in discourse wherever they may be through networks appropriate to their circumstances'. Distance Education is a source of by which globalization can be practiced. (Dimitris, 2008)

\section{NEED OF DISTANCE EDUCATION IN THE GLOBALIZED WORLD}

The Open and Distance Learning (ODL) universities/institutions have provide access to those persons who are lacking the formal qualifications to access the traditional universities. Globalization demands flexibility, with flexible people in continuous, lifelong learning. ODL universities give access to large number of learners who would otherwise have been unable to access education because of geographical distance or the inability to combine traditional studies with work. Those who disappear from work over longer periods of time tend to become peripheral in the workplace community.

The peripheral employees tend to get routine jobs; fewer opportunities for advancement; and are the first to go in times of rationalization. Most employees therefore are reluctant to engage in full time studies. Flexible learning that can be combined with a job, where the studies can be done at the workplace or at home, is ideal for learners who would otherwise have been excluded (Hardigan, 2004). 
In a globalized world, we need to have a learner friendly education. To meet this challenge institution must provide four skills that are required by the learners. During the course of studies through DE four basic skills have to be produced i-e Scientific, technological, application, and personal skills abbreviated as STAP (Mutthirulandi, 2003). Keeping in view the research students in DE the analyses of these skills are as follow:

\section{Scientific Skill}

This skill fosters researcher to acquire an understanding of scientific methods that are used either for analyzing or describing a fact in the research. This skill helps to develop the analytical aptitude of the learner. It means the knowledge of doing research in their respective disciplines.

\section{Technological Skill}

This is more concerned with the use of broad overview of the various technologies implemented in the research. This skill helps the researcher to become more efficient to collect their required materials for their field. In addition to it, researcher also develops some insights within himself/herself about the update technology, i.e. how it helps them in future to perform better. This employs that one has to know how to use technology in research.

\section{Application Skill}

In order to meet the demands of the research, researcher also need an in-depth fundamental knowledge of their specialized fields, general knowledge of problem solving methods, and finally particular application knowledge in accordance with research. Through this it can also be inferred that researcher has the knowledge of using skills required in research.

\section{Personal Skill:}

It helps the researcher to develop their thought on a certain fact or an issue, and use his/her work globalized world. One of the most visible manifestations of globalization is the emerging 'borderless' distance education market.

\section{CONCEPT OF QUALITY OF RESEARCH}

In operational terms the application of scientific method to inquiry is called research. Human inquiry wants to explore, explain and describe different things and phenomenon, while scientific method provides it logic and justifications. As Earl Points out that social research have many functions and purposes among them the major are exploration, explanation and description. (1998, p.90).

There are two major working areas for a researcher in research, one is conceptualization and second is operationalization. Earl explained it as "Conceptualization is the refinement and specification of abstract concepts and operationalization is the development of specific research procedures (operations) that will result in the empirical observations representing those concepts in the real world." (1998, p.139). 


\section{CONCEPT OF PLAGIARISM}

Plagiarism is a well-known term, but an extremely hard one to define in practice. The original meaning of the term was "kidnapping" although it has now come to mean the act of stealing or presenting as one's own the ideas, utterances or work of someone else. Grix quoted Rosamond outlines four ways in which plagiarism is generally understood:

$>$ Plagiarism reflects shoddy scholarship and the failure to meet the exacting standards expected in academic life.

$>$ Plagiarism is seen as an infringement of the informal practices that allow academic life to proceed; that is, a breakdown of trust between teacher and student, and among students themselves (2002).

There is confusion in the understanding of the nature of plagiarism, as students and teachers do not look at the issue in same way and also the policy makers have their own understandings which creates gap between all three entities. It is possible that there is dissimilarity in the response that suites best for academic dishonesty by students (Yeo, 2007). In universities, dishonesty is the main reason of bad behavior and it is clear from the major studies carried out in different teaching institutes worldwide. Academic delinquency appears to be prevalent in each and every discipline with little variations due to the differences in influencing factors such as type of assessment task. The disciplinary areas in which there is presence of carelessness in academic behavior, the reason is found to be lack of awareness. There are also other reasons such as work-load which cause academic dishonesty. In the results of some prototypes, there is indication that male students are more possible to detail cheating than female students. Men typically have lower levels of discipline making them more expected to cheat, and women have higher levels of predictable shame, making them less likely to give educational dishonesty (Yeo, 2007).

\section{TYPES OF PLAGIARISM}

There are two types of plagiarism, one is in which source is not cited and second is in which source is cited. Source not cited types of plagiarism:

$>$ The Ghost Writer: - the writer turns in another's work, word for word, as his/her own.

> The photocopy: - the writer copies significant portions of text straight from a single source, without alteration.

$>$ The potluck paper: - the writer tries to disguise plagiarism by copying from several different sources, tweaking the sentences retaining most of the original phrasing.

$>$ The Poor Disguise: - although the writer has retained the essential content of the source, he or she has altered the paper's words of phrases. 
> The Labor of Laziness; - the writer takes the time to paraphrase most of the paper from other sources and make it all fit together effort on original work.

$>$ The Self Stealer: - the writer borrows generously from his or her previous work, violating policies concerning the exceptions of that academic institution.

Source cited types of plagiarism:

$>$ The Forgotten Footnotes: - the writer mentions an author's name for a source, but neglects to include specific information on the footnote.

> The Misinformer: - the writer provides inaccurate information regarding the sources, making it impossible to find them.

$>$ The Too-Perfect Paraphrase: - the writer properly cites a source, but neglects to put in quotation marks text that has been copied work attributing the basic idea to the source.

$>$ The Perfect Crime: - in it writer tries to hide the original source altogether in his or her writing. (www.plagiraism.org/learinign)

Important terminology regarding plagiarism:

$>$ Attribution: -when writer provide proper acknowledgement to the author of the source called attribution.

> Bibliography: -a comprehensive list of all source used in the work.

$>$ Citation: -a short, formal indication of the source of information or quoted material.

$>$ Cite: -to indicate a source of information or quoted material in a short, formal note.

$>$ Common Knowledge: -information that is readily available from a number of sources, or so well-known that its sources do not have to be cited.

$>$ Copyright: -a law is protecting the intellectual property of individuals, giving them exclusive rights over the distribution and reproduction of that material.

$>$ Fair Use: -the guidelines for deciding whether the use of a source is permissible or constitutes copyright information.

> Paraphrase: -a restatement of a text or passage in other words.

$>$ Public Domain: -the absence of copyright protection; belonging to the public so that anyone may copy or borrow from it (www.plagiraism.org/learning)

\section{RESEARCH METHODOLOGY}

The present study is an applied study with respect to application, exploratory by objective and quantitative by paradigm. 
According to Gricx (2002) a questionnaire is a list of written questions that are answered marking the correct responses from the choice provided. The questionnaire may be considered as a formalized interview or interview by proxy. In the light of the objectives a five point rating scale questionnaire was prepared.

All concerning aspects regarding the objective of study were included in the questionnaire through which perception of the students could be possible. The questionnaire was sub divided into different parts.

The Study was delimited to the research students of education at PhD, M.Phil and MA level in AIOU, Islamabad. A sample of hundred students was selected through snowball sampling technique. Five point Likert scale questionnaire was used to collect the data. After pilot testing the refined questionnaire was distributed among the respondents by two means, self-administered and electronic mail.

The questionnaire prepared for the data collection was distributed to most of the respondents personally. Because this is the most reliable way of the distribution, to ensure it's reaching to the target. Ninety questionnaires received. Five were rejected due to incomplete responses. Frequencies of responses of different options under each item were obtained through tallies. Percentages of each component of the plagiarism types were worked out by combining the all levels of students. The tables showing frequencies and percentage regarding each of the items of questionnaire were prepared. To make the data more meaningful responses were combined (strongly agree +agree and strongly disagree+ disagree) and analysis were made on three points.

\section{DATA ANALYSIS}

Table: 1

Awareness about the concept of plagiarism

\begin{tabular}{|c|l|c|c|c|}
\hline Sr. & \multicolumn{1}{|c|}{ Statement } & \multicolumn{2}{c|}{ Options } \\
\cline { 3 - 5 } NO & \multicolumn{1}{|c|}{ Agree } & Undecided & Disagree \\
\hline 1 & $\begin{array}{l}\text { Copying and pasting from the internet can be done without } \\
\text { citing the source, because it is common knowledge. }\end{array}$ & $60 \%$ & $5 \%$ & $30 \%$ \\
\hline 2 & $\begin{array}{l}\text { When summarizing a block of text from another work, } \\
\text { citing the source at the end of your paper is sufficient. }\end{array}$ & $65 \%$ & $10 \%$ & $25 \%$ \\
\hline 3 & $\begin{array}{l}\text { One has to cite famous proverbs because they're common } \\
\text { knowledge. }\end{array}$ & $85 \%$ & $4 \%$ & $11 \%$ \\
\hline 4 & $\begin{array}{l}\text { Barrowing someone's idea and use it in a paper, without } \\
\text { reference it is not an act of plagiarism. }\end{array}$ & $67 \%$ & $5 \%$ & $23 \%$ \\
\hline 5 & $\begin{array}{l}\text { Using a few phrases from an article and mixing them with } \\
\text { your own words is not plagiarism. }\end{array}$ & $60 \%$ & $6 \%$ & $34 \%$ \\
\hline \multicolumn{2}{|l|}{ Mean Score } & 67 & 5 & 19 \\
\hline
\end{tabular}


The analyses of the data shows in the above table that majority of the students of all the levels agreed that copy pasting, summarizing without any source, citation of common knowledge, borrowing of ides and mixing of phrases are not the act of plagiarism.

Table: 2

Kowledge about the specific terminologies

\begin{tabular}{|c|c|c|c|c|}
\hline \multirow[t]{2}{*}{$\begin{array}{l}\text { Sr. } \\
\text { NO }\end{array}$} & \multirow[t]{2}{*}{ Statement } & \multicolumn{3}{|c|}{ Options } \\
\hline & & Agree & Undecided & Disagree \\
\hline 1 & $\begin{array}{l}\text { Bibliography is a list of some sources used in } \\
\text { preparing a work. }\end{array}$ & $71 \%$ & $8 \%$ & $21 \%$ \\
\hline 2 & $\begin{array}{l}\text { Citation is a comprehensive and informal indication } \\
\text { of the source of information or quoted material. }\end{array}$ & $83 \%$ & $7 \%$ & $10 \%$ \\
\hline 3 & $\begin{array}{l}\text { Common knowledge is that information which is } \\
\text { availableon some selected sources. }\end{array}$ & $65 \%$ & $4 \%$ & $31 \%$ \\
\hline 4 & $\begin{array}{l}\text { Copyright is a law which provides little protection to } \\
\text { the intellectual work of individuals. }\end{array}$ & $69 \%$ & $6 \%$ & $25 \%$ \\
\hline 5 & $\begin{array}{l}\text { Paraphrasing is a statement which can be made by } \\
\text { changing few words from the original text. }\end{array}$ & $73 \%$ & $8 \%$ & $19 \%$ \\
\hline & Mean Score & 72 & 5 & 21 \\
\hline
\end{tabular}

The finding in the above table reflects that the majority of respondents have no clear idea about the terminologies like bibliography, citation, common knowledge, copyright and paraphrasing.

Table: 3

Types of plagiarism

\begin{tabular}{|c|c|c|c|c|}
\hline \multirow[t]{2}{*}{ Sr. NO } & \multirow[t]{2}{*}{ Statement } & \multicolumn{3}{|c|}{ Options } \\
\hline & & Agree & Undecided & Disagree \\
\hline 1 & $\begin{array}{l}\text { Plagiarism may be divided into two } \\
\text { types i.e. source citied plagiarism } \\
\text { and source not cited plagiarism. }\end{array}$ & $85 \%$ & $7 \%$ & $13 \%$ \\
\hline 2 & $\begin{array}{l}\text { The "Ghost Writer" is a type of } \\
\text { source not cited plagiarism. }\end{array}$ & $66 \%$ & $10 \%$ & $24 \%$ \\
\hline 3 & $\begin{array}{l}\text { The "Forgotten Footnote" } \\
\text { is a type of source cited plagiarism. }\end{array}$ & $79 \%$ & $14 \%$ & $7 \%$ \\
\hline 4 & $\begin{array}{l}\text { The "Self-Stealer" is a type of } \\
\text { source cited plagiarism. }\end{array}$ & $81 \%$ & $11 \%$ & $8 \%$ \\
\hline 5 & $\begin{array}{l}\text { "The Too-Perfect Paraphrase" } \\
\text { is a type of source cited plagiarism. }\end{array}$ & $74 \%$ & $9 \%$ & $17 \%$ \\
\hline & Mean Score & 77 & 10 & 14 \\
\hline
\end{tabular}


The finding in the above table indicates that the majority of respondents have no clear idea about the types like cited and not cited plagiarism, Ghost writer, forgotten note, Self-Stealer and Too-Perfect Paraphrase.

Table: 4

Consequences of plagiarism

\begin{tabular}{|c|c|c|c|c|c|}
\hline \multirow{3}{*}{$\begin{array}{l}\text { Sr. } \\
\text { NO }\end{array}$} & \multirow{2}{*}{\multicolumn{2}{|c|}{ Statement }} & \multicolumn{3}{|c|}{ Options } \\
\hline & & & \multirow[t]{2}{*}{ I Know } & \multirow[t]{2}{*}{ Undecided } & \multirow[t]{2}{*}{ Unaware } \\
\hline & Type of offence & Suggested Penalty & & & \\
\hline 1 & $\begin{array}{l}\text { First minor offence e.g. } \\
\text { unreferenced material, } \\
\text { joint submission }\end{array}$ & $\begin{array}{l}\text { Coursework mark is set } \\
\text { zero }\end{array}$ & $17 \%$ & $5 \%$ & $78 \%$ \\
\hline 2 & $\begin{array}{l}\text { Author who let others } \\
\text { have copies of their work }\end{array}$ & $\begin{array}{l}\text { Coursework mark } \\
\text { is set zero }\end{array}$ & $20 \%$ & $5 \%$ & $75 \%$ \\
\hline 3 & $\begin{array}{l}\text { Second offence will be } \\
\text { referred to a panel }\end{array}$ & $\begin{array}{l}\text { Referred to Assessment } \\
\text { Offences Panel, student } \\
\text { may be asked to leave } \\
\text { the university }\end{array}$ & $18 \%$ & $8 \%$ & $74 \%$ \\
\hline 4 & $\begin{array}{l}\text { Second offence will be } \\
\text { referred to a panel }\end{array}$ & $\begin{array}{l}\text { Referred to Assessment } \\
\text { Offences Panel, student } \\
\text { may be asked to leave } \\
\text { the university }\end{array}$ & $14 \%$ & $6 \%$ & $80 \%$ \\
\hline 5 & $\begin{array}{l}\text { First major offence } \\
\text { e.g. plagiarism bulk } \\
\text { of a project }\end{array}$ & $\begin{array}{l}\text { Referred to Assessment } \\
\text { Offence Panel, student } \\
\text { may be asked to leave } \\
\text { the university }\end{array}$ & $23 \%$ & $8 \%$ & $69 \%$ \\
\hline \multicolumn{3}{|c|}{ Mean Score } & 18 & 6 & 75 \\
\hline
\end{tabular}

The finding in the above table reflects that the majority of respondents have no clear idea about the types like cited and not cited plagiarism, Ghost writer, forgotten note, SelfStealer and Too-Perfect Paraphrase.

\section{CONCLUSION AND DISCUSSION}

In the survey, regarding the conceptual awareness of research students in Distance Education it was found through the responses of students about:

$>$ Awareness about the concept of plagiarism

$>$ Knowledge about the specific terminologies

$>$ Types of plagiarism

$>$ Consequences of plagiarism, that students have no clear idea about the concept of plagiarism, they have no concept abut terminologies, they have no clear idea about the types and unaware about the HEC penalties about plagiarism. 
It shows that students are unaware about the concept of plagiarism and they do it unintentionally in their research work. It also reflects that in their research course work they are not well informed about the concept of plagiarism and the consequences of it. The data also indicated that students are not well aware about the standards and ethics of research. The finding of the study is supported by the findings of many studies like Gulam, (2013) reported that student are unaware about the HEC plagiarism policy. Academic misconduct in students planning careers in business, science, engineering and technology in various academic institutes in USA has also been reported McCabe (1995). In United Kingdom, the incidence of plagiarism and dishonest behaviors in research work situations has been observed in distance education undergraduates, with a finding that most infringements occurred (Aggarwal, 2002). In Canada also, high prevalence of research student's self-reported use of dishonest behaviors has been narrated (Austin, 2006).

In the light of findings an extensive lack was found in the understanding of students towards the conceptual awareness about plagiarism. Universities main function is to create new knowledge through researches and these research works have to be shared locally and globally as well. So for the improvement of research practices in distance education, research standards have to be followed. To maintain research standards and quality in research work students of distance education have to be educated about the concept of plagiarism. The course work of research may have content about plagiarism.

\section{BIODATA and CONTACT ADDRESSES of AUTHORS}

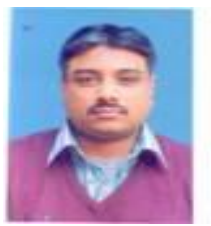

Sheikh Tariq MAHMOOD is a Lecturer in International Islamic university Islamabad. He did master in Educational Planning and Management and Mphil (Education) from Allama Iqbal Open University Islamabad. He is a scholar of PhD in Preston University. He is also coordinator of Allama Iqbal Open University Islamabad.

Lecturer Sheikh Tariq MAHMOOD

International Islamic University, PAKISTAN

Phone: 092-51-9019406

Email:tariq iiui@hotmail.com

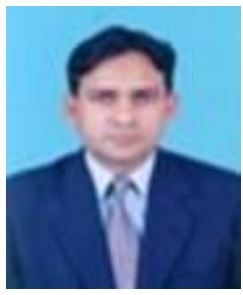

Dr Azhar MAHMOOD did M.sc (Psychology) and M.Ed from university of Punjab, Lahore, Pakistan. He obtained PhD degree in Education from National University of Modern Languages, Islamabad. He is supervising research work at the International Islamic University, Islamabad and teaching at Master and Mphil levels. His areas of interest are Educational Psychology, Early Childhood, Guidance and Counseling, Research Methods and Statistics. He has presented number of research papers at national and international education conferences 
Lecturer Dr. Azhar MAHMOOD

International Islamic University, PAKISTAN

Phone: 092-51-9019407

Email: azhar.mahmood62@yahoo.com

\section{REFERENCES}

Aggarwal, R., Bates, I., Davies J. G. (2002). A Study of Academic Dishonesty among Students at two Pharmacy Schools. Pharm J; 269 (7219).529-533.

Austin, Z., Collins, D., Remillard, A. (2006). Influence of Attitudes toward Curriculum on Dishonest Academic Behavior. Am J Pharm Educ. 70(3). 50.

Charles, J. (2006). Overcoming the Cultural Issues Associated with Plagiarism for International Students. Aberdeen: University Press.

De Lambert K, Ellen, N., Taylor, L. (2006).Chalkface challenges: a study of academic dishonesty amongst students in New Zealand tertiary institutions. Assess Eval Higher Educ. 31(5): 485-503.

Earl, B. (1998). Survey Research Methods ( $2^{\text {nd }}$ ed $)$. Belmont CA: Wadsworth.

Fink, A. (1998). Conducting Research Literature Reviews, Sage Publications, Inc. New Delhi, India

Gay, L. R. (2000). Educational Research; Competencies for Analysis and Application, ( $5^{\text {th }}$ ed.) Rawalpindi: S.T Printers.

Ghulam, M. (2013).Evaluation of Student's Perception And BehaviorTowards Plagiarism in Pakistani Universities. ActaBioethica.19 (1).125-130.

Grix, J. (2002). The Foundation of Research. New York: Palgrave.

Hardigan, P. C. (2004). First- and third-year Pharmacy students' attitudes toward cheating behaviors. Am J Pharm Educ. 68(5). 110.

Higher Education Commission of Pakistan (2006). The Little Book of Plagiarism, What it is and How to avoid it, XV

Marsden, H., Carroll, M., Neill J. T. (2005). Who Cheats At University: A Self-Report Study Of Dishonest Academic Behaviors in a Sample of Australian University Students? Aust J Psychol. 57(1).1-10.

McCabe, D. L., Trevino, L. K. (1995). Cheating among Business Students: A Challenge for Business Leaders and Educators. J Manag Educ.19 (2).205-218. 
Mutthirulandi, R. (2003). Globalization and Education: Need for Curriculum for LifelongLearning Programs. http://www.boloji.com/analysis/068.htm. Accessed 25thSeptember, 2007.

Sethy, S. S. (2008). Distance Education in the Age of Globalization: An Overwhelming Desire towards Blended Learning. Turkish Online Journal of Distance Education. ISSN 1302-6488 Volume: 9 Number: 3 Article 3.

Yeo, S. (2007).First-Year University Science and Engineering Students' Understanding of Plagiarism. Higher Educ Res Dev. 26(2).199-216.

http//www.plagiraism.org/learning center/typws of plagiarism.html 